\title{
ARTICLE
}

Received 10 May 2014 | Accepted 2 Oct 2014 | Published 13 Nov $2014 \quad$ DOl: 10.1038/ncomms6453

\section{Seismic reflection data support episodic and simultaneous growth of the Tibetan Plateau since $25 \mathrm{Myr}$}

Xiao-Dian Jiang ${ }^{1} \&$ Zheng-Xiang $\mathrm{Li}^{2}$

The spectacular topography of the Tibetan Plateau is the result of collision between India and Eurasia over some $50 \mathrm{Myr}$, but how the plateau grew to its present size remains a topic of debate. Work along its eastern margin suggests a two-stage uplift (thus growth of the plateau) since 30-25 Myr. Here we report high-resolution seismic reflection and drill core results from the southern Tarim Basin that indicate a similar pattern for the northern margin of the plateau. The data suggest that uplift in northern Tibet started at $\sim 23 \mathrm{Myr}$ from near sea level, with the first episode finished by $\sim 10$ Myr, followed by a post-5-Myr episode of rapid uplift along the present plateau margin. The growth of the Tibetan Plateau after the Eocene thus appears to have been episodic in nature, and near-synchronous along both eastern and northern margins.

\footnotetext{
${ }^{1}$ Department of Marine Geology, Ocean University of China, 238 Songling Road, Qingdao, China. ${ }^{2}$ ARC Centre of Excellence for Core to Crust Fluid Systems (CCFS) and the Institute for Geoscience Research (TIGeR), Department of Applied Geology, Curtin University, GPO Box U1987, Perth, Western Australia 6845, Australia. Correspondence and requests for materials should be addressed to Z.-X.L. (email: z.li@curtin.edu.au).
} 
O pinions regarding the rise of the Tibetan Plateau range from synchronous plateau-wide uplift $^{1}$ to stepwise northward plateau growth ${ }^{2}$. Recent work along the eastern margin of the plateau demonstrates two episodes of rapid uplift: one from 30 to $25 \mathrm{Myr}$ and another from 15 to $10 \mathrm{Myr}$ (ref. 3), which appears to favour the episodic plateau growth model. Work along the West Kunlun Range at the northwest margin of the Tibetan Plateau, however, has led to diverse conclusions, ranging from three-episode uplift ${ }^{4}$ to a single post-4.5 Myr uplift ${ }^{5}$. Estimations for the initiation of uplift range from $\sim 46 \mathrm{Myr}$ to $\sim 3 \mathrm{Myr}$ (refs $4-13$ ) based on a variety of approaches: $\sim 46 \mathrm{Myr}$ based on stratigraphic and sedimentary analysis ${ }^{6} ; \quad 37-30 \mathrm{Myr}$ based on chronology and lithostratigraphy ${ }^{2,7,8}$; $\sim 25-15 \mathrm{Myr}$ based on fission track dating ${ }^{9}$, thermochronological results ${ }^{10}$ and $\mathrm{Nd}$ isotopic analysis of dust ${ }^{11}$ and $\sim 4.5 \mathrm{Myr}$ or younger based on magnetostratigraphic and palaeo-environmental analyses $4,5,12,13$. No previous attempt has been made to constrain the uplift history using the subsurface stratigraphic record in the desert-covered Tarim Basin apart from a mentioning in a regional overview ${ }^{14}$.

The continental lithosphere of the Tarim Block underthrusts northern Tibet to its south ${ }^{15-18}$, with up to $12 \mathrm{~km}$ thick of Cenozoic foreland basin deposits accumulated along southern Tarim due to the loading of the plateau ${ }^{6}$. These deposits provide a unique record of the history of the mountain building ${ }^{19}$. Here we report the results of two high-quality petroleum prospecting seismic lines and two drill holes from the foreland basin in southwestern Tarim, which enable us to independently estimate the timing and rate of plateau uplift along the northwestern margin of the Tibetan Plateau. Our work points to two episodes of uplift from near sea level since $\sim 23 \mathrm{Myr}$, and we conclude that the growth of the Tibetan Plateau since the Eocene has been episodic and near-synchronous along its eastern and northern margins.

\section{Results}

Geological setting. Our study region is located at the piedmont of the West Kunlun Range, which marks the northwestern edge of the Tibetan Plateau (Fig. 1). The West Kunlun orogenic belt is bounded to the south by the Karakax Fault and to the north by the Tekilik Fault ${ }^{17,20}$. It is characterized by high topographic relief with elevation of up to $6,500 \mathrm{~m}, 4,000-5,000 \mathrm{~m}$ higher than the average elevation of the southwestern Tarim foreland basin. The Tarim Block to the north has an Archaean to Proterozoic crystalline basement. Shallow-marine limestone and calcareous shale were deposited for much of the time from the Cambrian until at least $\sim 25 \mathrm{Myr}$, and could be as late as $\sim 15 \mathrm{Myr}^{10,21}$. Sequence stratigraphic boundaries and their ages within the study region are based on the fossil record and lateral correlations with type sections of the Tarim basin ${ }^{22,23}$. Palaeocene and Eocene strata developed in restricted areas only in the Tarim Basin ${ }^{22}$, and drill-hole data reveal a depositional hiatus between the Permian and the Oligocene in the study region. The Cenozoic strata here exhibit a general coarsening upward trend (Fig. 2). The $\sim 130-\mathrm{m}-$ thick Oligocene Bashiblake Formation $\left(\mathrm{E}_{3}^{1}\right)$ marine carbonate platform deposits ${ }^{13,23}$ mark the end of marine carbonate deposition in the basin. The Miocene Wuqia Group $\left(\mathrm{N}_{1}\right)$ consists of clastic tidal flat (the Keziluoyi $\mathrm{N}_{1}^{1}$ and Anjuan $\mathrm{N}_{1}^{2}$ formations) and mixed flat facies (the Pakbulak Formation $\mathrm{N}_{1}^{3}$ ), with lithology including a series of marine and terrestrial sandstone, shale and mudstone. This group exhibits a progressively higher-energy depositional environment ${ }^{22,23}$. The Pliocene Artux formation $\left(\mathrm{N}_{2}\right)$ comprises dominantly fluvial and alluvial-fan deposits, marking the emergence of the continent above sea level. This was followed by the deposition of the

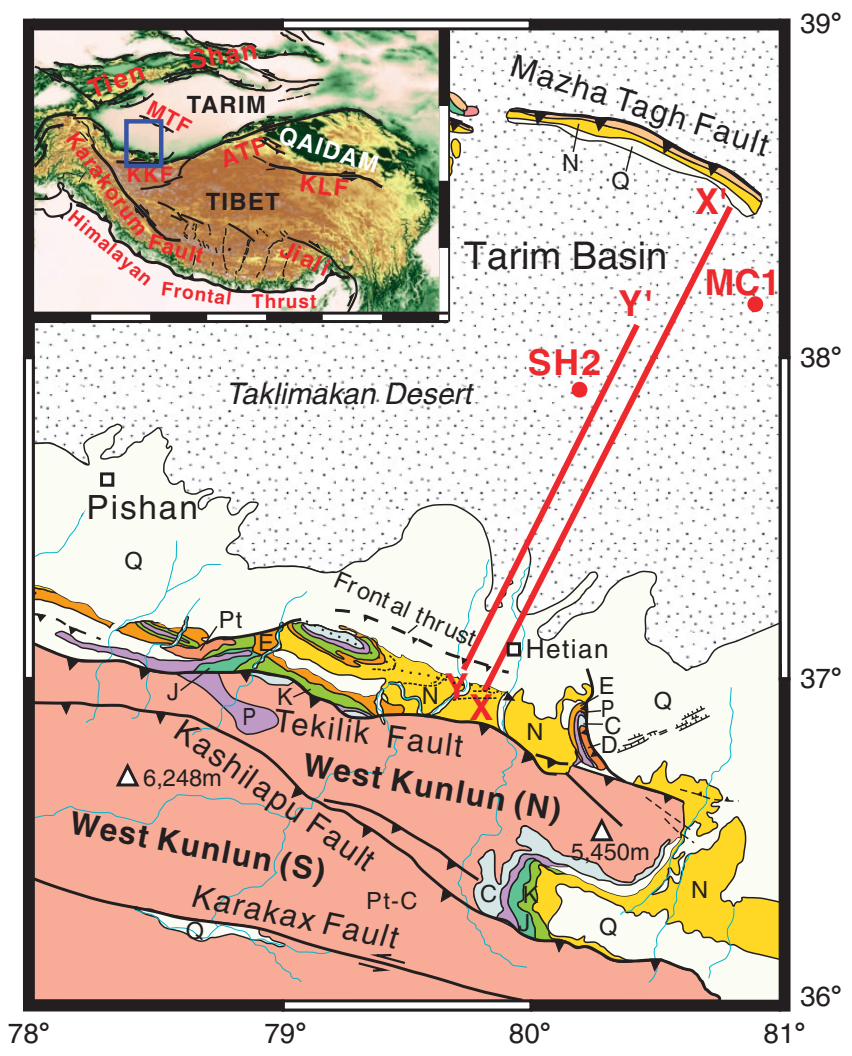

Figure 1 | Regional map. Simplified geological map of the West Kunlun Range and adjacent areas (after 22), showing the location of the two seismic reflection transects (red lines). Red dots show the locations of the two drill holes: SH2 (Shenghe2) and MC1 (Macan1). Inset shows the tectonic framework with relative topography after (ref. 29), where the blue rectangle marks the location of the study region. Ages of geological units: Pt-Proterozoic; D-Devonian; C-Carboniferous; P-Permian; E-Paleogene; N-Neogene; Q-Quaternary (mainly Pleistocene). $\mathrm{ATF}=$ Altyn Tagh Fault; KKT $=$ Karakax Fault; KLF = Kunlun Fault; MTF = Mazha Tagh Fault.

Pleistocene Xiyu formation (Q) alluvial-fan conglomerates intercalated with lenses of siltstone ${ }^{22-24}$ (Fig. 2), indicating that the uplifted West Kunlun orogen was by then adjacent to the study region.

Seismic reflection data and foreland basin geometry. Seismic reflection and drill-hole data were acquired in the foothills of the West Kunlun Range and the southwestern Tarim foreland basin for petroleum prospecting by the Shengli Oilfield Company during 1997-2000, and the data of two transects $\left(\mathrm{X}-\mathrm{X}^{\prime}\right.$ and $\left.\mathrm{Y}-\mathrm{Y}^{\prime}\right)$ and two wells ( $\mathrm{MC1}$ and $\mathrm{SH} 2$; for locations see Fig. 1) were provided to the Ocean University of China for scientific purposes under a scientific cooperation agreement. As the two parallel transects, $\sim 10 \mathrm{~km}$ apart, show similar structures (Fig. 3), and transect $\mathrm{BB}^{\prime}$ has a higher resolution, we combined them into a single transect to strengthen the image with transect $\mathrm{Y}_{-} \mathrm{Y}^{\prime}$ joined with the northeastern section of transect $\mathrm{X}-\mathrm{X}^{\prime}$ using the ProMax Oil software. The joint seismic transect was converted to a depthmigrated section constrained by synthetic seismogram of VSP velocity of wells MC1 and SH2 (Fig. 4a).

The foreland deposits dip gently to the southwest, and thicken by $\sim 9 \mathrm{~km}$ over the distance of $\sim 170 \mathrm{~km}$, indicating a clear image of the wedge-shaped foreland basin geometry (Fig. 4a). The folds and thrusts revealed in the transect show that the thrust belt has been progressively incorporating the foreland basin over time. 


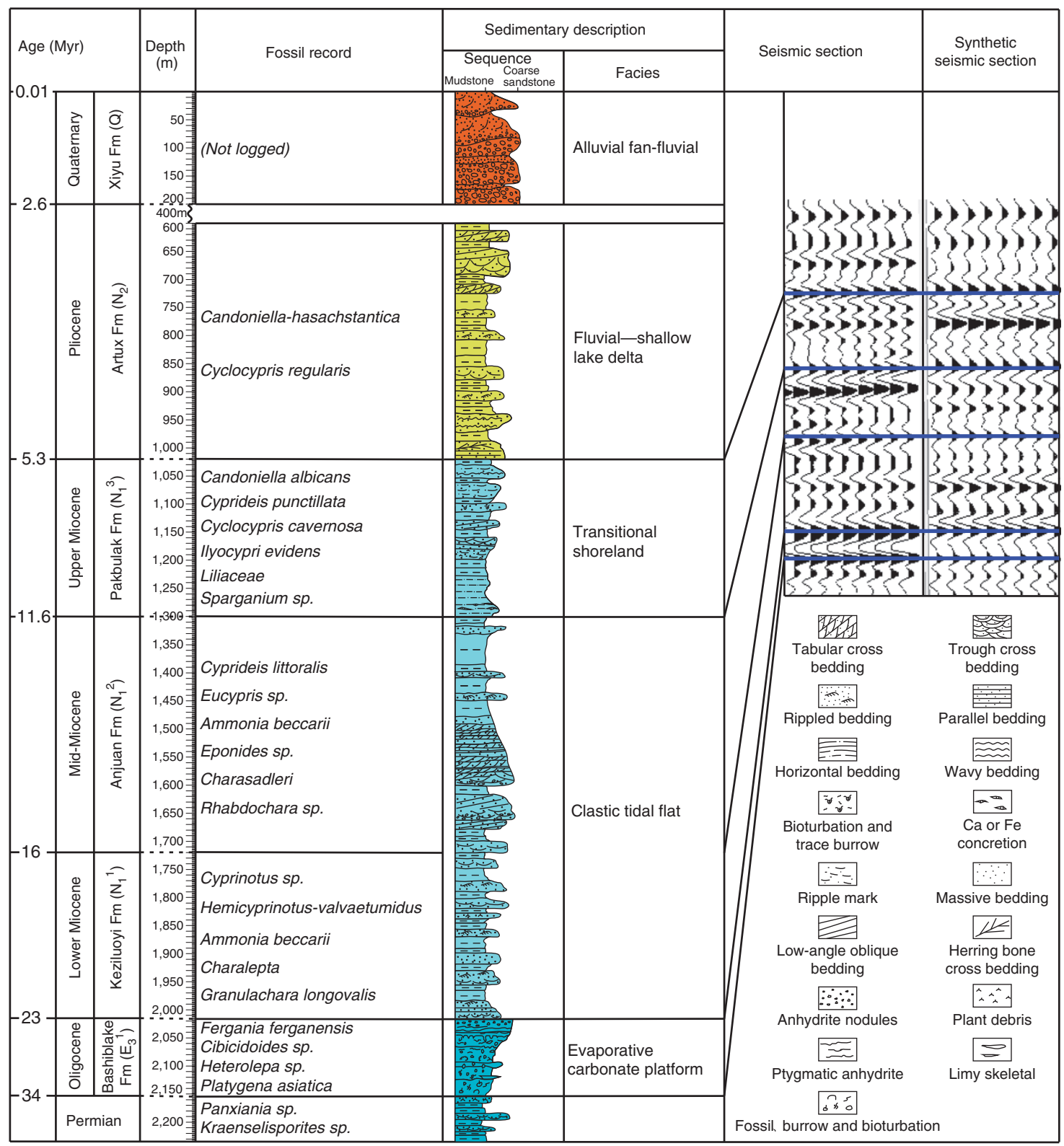

Figure 2 | Stratigraphic column. Data are from well MC1 located to the north east of the study area, compiled from (ref. 23). Quaternary strata cut by the top $\sim 500 \mathrm{~m}$ of the drill hole were not logged. Logging of synthetic seismic records of well $\mathrm{MC} 1$ is comparable to seismic reflection data, and both consistently show layer interfaces of $E_{3}^{1} / N_{1}^{1}, N_{1}^{1} / N_{1}^{2}, N_{1}^{2} / N_{1}^{3}$ and $N_{1}^{3} / N_{2}$ strata. Sedimentary facies and palaeontological information are from regional compilations by (refs $22,23,25$ ).

Syntectonic growth strata began to accumulate in the early Miocene, with the Keziluoyi Formation, a tidal-flat succession, marking a sharp break from the underlying marine platform carbonates of the Bashiblake Formation $\left(\mathrm{E}_{3}^{1}\right)^{23}$. Marine foraminifera Ammonia beccarii and ostracod Hemicyprinotus valvaetumidus of the Keziluoyi Formation are found in both well $\mathrm{MC1}$ and outcrops in the southwestern Tarim Basin ${ }^{22,25}$. An age range of $\sim 23-16 \mathrm{Myr}$ is assigned to the formation following the recent geological timescale ${ }^{26}$. Likewise, fossil-constrained ages bracket the Anjuan Formation at 16-11.6 Myr, the Pakabulake Formation at $11.6-5.3 \mathrm{Myr}$ and the Artux Formation at 5.3-2.6 Myr (refs 22,23) (Fig. 2).

Time for the onset of uplifting in the West Kunlun Range. The change in sedimentary environment from a marine carbonate platform in the Oligocene (the Bashiblake Formation, $\mathrm{E}_{3}^{1}$ ) to a clastic tidal flat in the early Miocene (the Keziluoyi Formation, $\mathrm{N}_{1}^{1}$ in Figs 2 and $4 b, c)$ marks the beginning of foreland basin development due to the formation of the proto-West Kunlun Range at the northern edge of the proto-Tibetan Plateau. The estimated $\sim 23 \mathrm{Myr}$ initiation age for the uplift of the proto-West Kunlun Range, based on seismic stratigraphy and the fossil record, is consistent with 22.1-13.7 Myr apatite fission track ages for gneisses in the West Kunlun Range front ${ }^{9}$. It is also consistent with the $\sim 25 \mathrm{Myr}$ age for north-south contraction along the Pamir-West Kunlun Range ${ }^{27}$, the 25-23 Myr ages for large-scale dextral strike-slip movements in northwestern Tibetan Plateau ${ }^{28}$ and the 25-20 Myr ages for rapid exhumation at northern Tibet ${ }^{9}$.

As the orogen grew higher and possibly also extended to the southern part of the Tarim Basin due to the northward propagation of the Tibetan Plateau, high-energy tidal sediments 

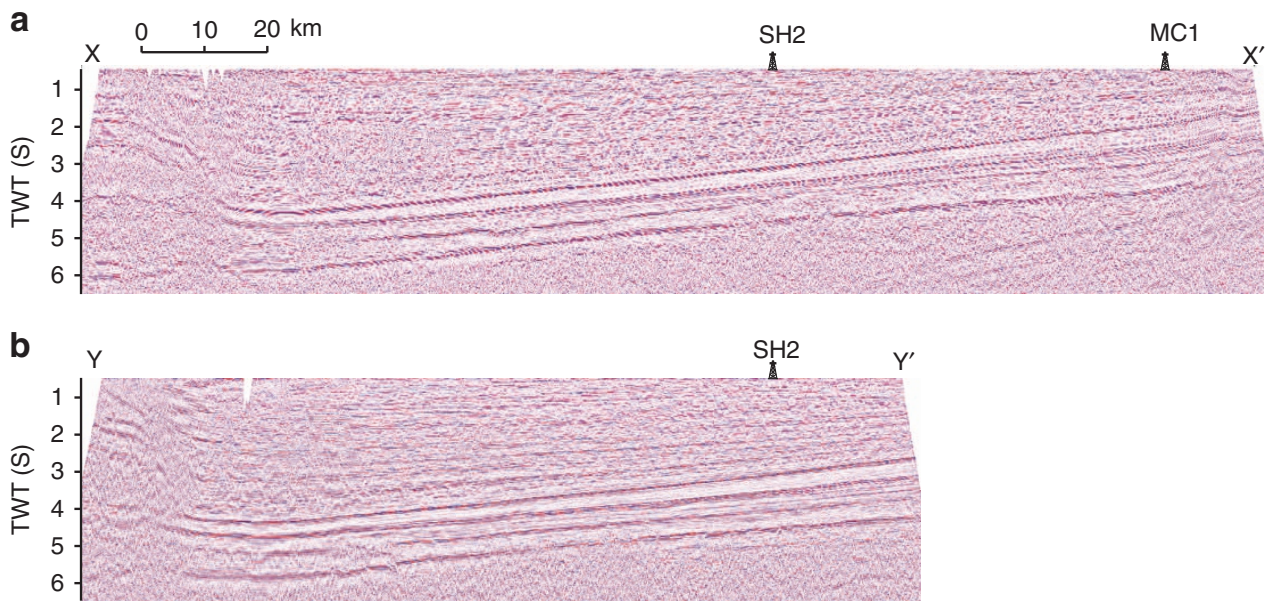

Figure 3 | Original seismic data. (a) Seismic reflection results along transect $X-X^{\prime}$. The projected locations of wells $M C 1$ and $S H 2$ on the transect are shown. (b) Seismic reflection results along transect $Y-Y^{\prime}$, with the projected location of well $\mathrm{SH} 2$ shown.
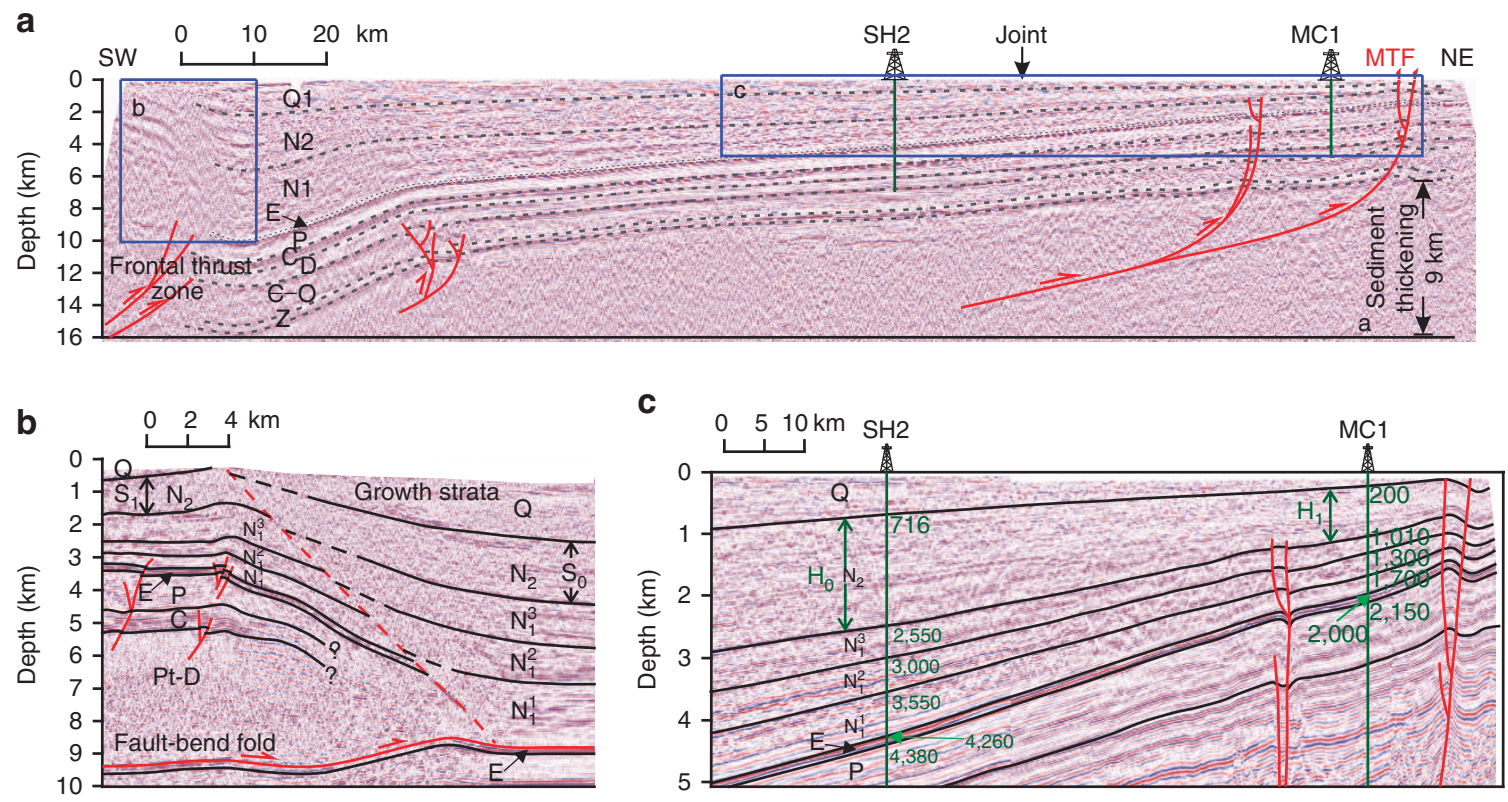

Figure 4 | Interpreted seismic data and basin geometry. (a) Geological interpretation of the composite seismic reflection transect across the front of the West Kunlun thrust belt and its foreland basin, using results from two seismic profiles $X-X^{\prime}$ and $Y-Y^{\prime}$ (Fig. 3; see Fig. 1 for locations) with the junction marked by 'Join'. Wells MC1 and SH2 are projected onto the plane of the transect. Dotted lines are interpreted stratigraphic boundaries. The surface of the basement shows a 9-km subsidence towards the thrust belt. (b) Detailed interpretation of seismic reflection data across the frontal thrust, showing a fault-bend fold and growth strata. (c) Detailed foreland basin stragraphic interpretation as constrained by drill holes SH2 and MC1. Numbers in green are depths in metres. Both (a) and (c) show that the growth strata are post-Oligocene (marked as E) in age. Pt-Proterozoic; Z-Neoproterozoic; $\in$ - Cambrian; O-Ordovician; D-Devonian; C-Carboniferous; P-Permian; E-Paleogene; N-Neogene; Q-Quaternary.

were deposited (the Anjuan and Pakbulake formations, $\mathrm{N}_{1}^{2}$ and $\mathrm{N}_{1}^{3}$; Fig. 2). Since the Pliocene, the sedimentary facies became dominantly fluvial and alluvial fans (the Artux and Xiyu Formations, $\mathrm{N}_{2}$ and Q; Fig. 2).

Rates of episodic uplift and basin subsidence. A quantitative estimation of differential sedimentation rates in the foreland basin can be made utilizing the high-resolution seismic data (Figs 4 and $5 \mathrm{a}$, including locations of drill holes), constrained by the drill-hole data and the fossil record (Fig. 2). This allows us to estimate the rates of differential uplift between the two sides of the frontal thrust in the West Kunlun Range (Fig. 1), as well as subsidence rates in the foreland basin. These estimations shed new light on both the episodic nature of plateau propagation and variations in the intensity of orogenic uplift (plateau propogation) with time.

We use the thickness variations in the foreland basin to calculate the changing rate of sedimentation with time at different locations in the foreland basin (see locations 1 to 12 marked along the seismic traverse in Fig. 5a), calibrated by the sedimentation record in wells $\mathrm{SH} 2$ and $\mathrm{MC} 1$ where the strata thicknesses are marked as $\mathrm{H}_{0}$ and $\mathrm{H}_{1}$, respectively (Fig. 4c). Assuming equilibrium subsidence versus deposition rates in the tidal-flat to fluvial/aluvial fan environments, the average deposition (subsidence) rates are given in Table 1 and shown in Fig. 5b. The 12 locations across the foreland basin show a consistent pattern in the change of deposition/subsidence rate with time, 

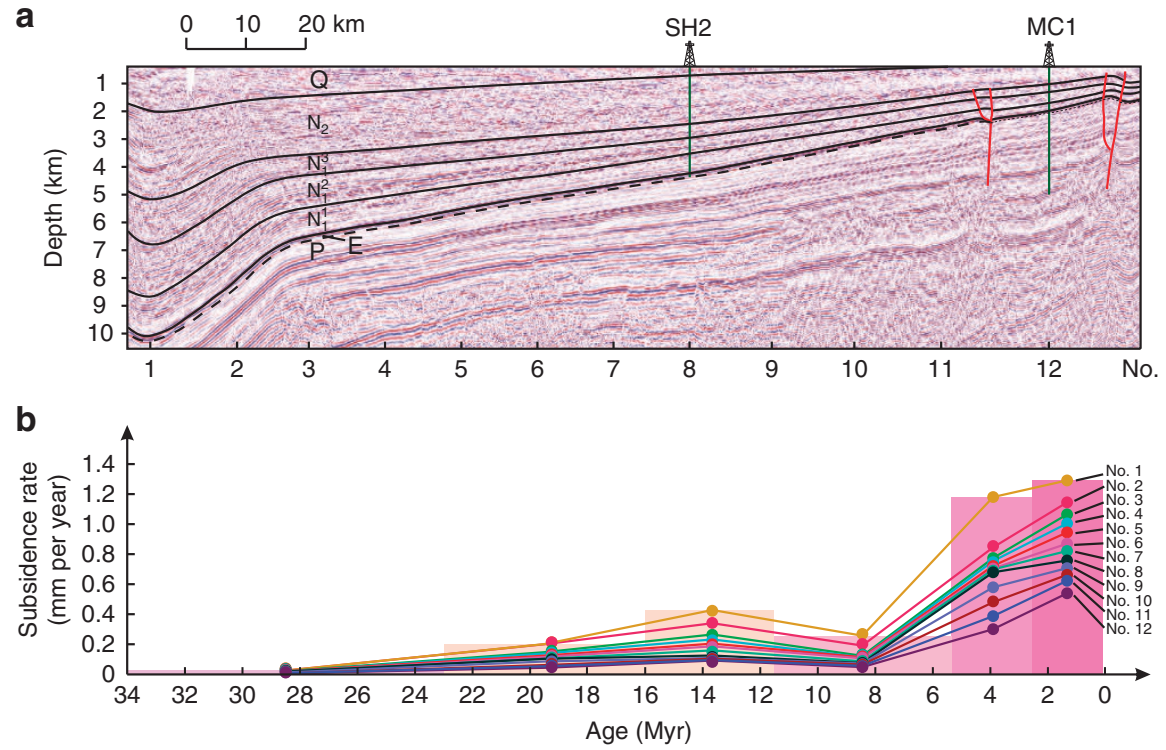

Figure 5 | Time-space variations in foreland subsidence rate. (a) Stratigraphic interpretation of the composite seismic transect constrained by drill holes $\mathrm{MC} 1$ and $\mathrm{SH} 2$, showing the geometry of the Cenozoic at foreland basin and older strata. The growth strata of post-Oligocene age, thickening to the southwest, are easily recognizable. Numbers at the bottom of the figure show positions of the 12 locations used for calculating the foreland basin subsidence rates in (b). P-Permian; E-Paleogene; N-Neogene; Q-Quaternary. (b) Calculation results of subsidence rate changes with time for the 12 locations along the seismic transect as shown in (a), using strata thickness as determined by the seismic data calibrated using drill-hole data (Figs 2 and 3), with age constraints provided by the fossil record (Fig. 2). The shaded columns indicate time intervals for the estimated data points. Calculation results are given in Table 1.

Table 1 | Results of subsidence rate calculation.

\begin{tabular}{|c|c|c|c|c|c|c|c|c|c|c|c|c|}
\hline \multirow{3}{*}{$\begin{array}{l}\text { Stratum } \\
\Delta \mathbf{t} \\
\text { (Myr) } \\
\end{array}$} & \multirow{2}{*}{\multicolumn{2}{|c|}{$\frac{Q}{0.01-2.6}$}} & \multirow{2}{*}{\multicolumn{2}{|c|}{$\frac{\mathrm{N}_{2}}{5.3-2.6}$}} & \multirow{2}{*}{\multicolumn{2}{|c|}{$\frac{N_{1}^{3}}{11.6-5.3}$}} & \multirow{2}{*}{\multicolumn{2}{|c|}{$\frac{N_{1}^{2}}{16-11.6}$}} & \multirow{2}{*}{\multicolumn{2}{|c|}{$\frac{N_{1}^{1}}{23-16}$}} & \multirow{2}{*}{\multicolumn{2}{|c|}{$\frac{E_{3}^{1}}{34-23}$}} \\
\hline & & & & & & & & & & & & \\
\hline & $\begin{array}{c}\mathbf{H} \\
(\mathrm{m})\end{array}$ & $\begin{array}{c}\mathbf{V} \text { (mm per } \\
\text { year) }\end{array}$ & $\begin{array}{c}\mathbf{H} \\
(\mathrm{m})\end{array}$ & $\begin{array}{c}\mathbf{V} \text { (mm per } \\
\text { year) }\end{array}$ & $\begin{array}{c}\mathbf{H} \\
(\mathrm{m})\end{array}$ & $\begin{array}{c}\mathbf{V} \text { (mm per } \\
\text { year) }\end{array}$ & $\begin{array}{c}\mathbf{H} \\
(\mathrm{m})\end{array}$ & $\begin{array}{c}V \text { (mm per } \\
\text { year) }\end{array}$ & $\begin{array}{c}\mathbf{H} \\
(\mathrm{m})\end{array}$ & $\mathbf{v}$ & $\begin{array}{c}\mathbf{H} \\
(\mathrm{m})\end{array}$ & $\begin{array}{c}\mathbf{V} \text { (mm per } \\
\text { year) }\end{array}$ \\
\hline No. 1 & 3,346 & 1.291 & 3,186 & 1.180 & 1,620 & 0.257 & 1,883 & 0.428 & 1,409 & 0.201 & 193 & 0.018 \\
\hline No. 2 & 2,965 & 1.145 & 2,281 & 0.845 & 1,204 & 0.191 & 1,497 & 0.340 & 1,400 & 0.200 & 284 & 0.026 \\
\hline No. 3 & 2,758 & 1.065 & 2,091 & 0.774 & 755 & 0.120 & 1,167 & 0.265 & 1,030 & 0.147 & 175 & 0.016 \\
\hline No. 6 & 2,294 & 0.886 & 1,902 & 0.704 & 628 & 0.100 & 820 & 0.186 & 718 & 0.103 & 172 & 0.016 \\
\hline No. 7 & 2,127 & 0.821 & 1,884 & 0.698 & 563 & 0.089 & 700 & 0.159 & 704 & 0.101 & 162 & 0.015 \\
\hline No. 8 & 1,964 & 0.758 & 1,834 & 0.679 & 450 & 0.071 & 550 & 0.125 & 710 & 0.102 & 120 & 0.011 \\
\hline No. 9 & 1,831 & 0.707 & 1,562 & 0.579 & 439 & 0.070 & 462 & 0.105 & 593 & 0.085 & 130 & 0.013 \\
\hline No. 10 & 1,719 & 0.664 & 1,310 & 0.485 & 365 & 0.058 & 443 & 0.101 & 461 & 0.066 & 156 & 0.014 \\
\hline No. 11 & 1,615 & 0.623 & 1,045 & 0.387 & 305 & 0.048 & 420 & 0.095 & 368 & 0.053 & 135 & 0.012 \\
\hline
\end{tabular}

with one low peak during the mid-Miocene $(\sim 16-11 \mathrm{Myr})$ and a high peak during the Quaternary (after $\sim 2.6 \mathrm{Myr}$ ). The fact that data points inside or close to the orogen (that is, locations 1 and 2) and those away from the orogen (locations 3 to 12) show the same time-variation pattern indicates that the pattern can not be explained by factors such as lithospheric softening within the orogen. The time-variation in deposition/ subsidence rate thus most likely reflects changes in the orogenic loading on the lithosphere of the Tarim Block, which would have resulted in isostasy-driven surface uplift at the present northwestern margin of the Tibetan Plateau. The rate estimations for location No. 1 near the depocenter (Fig. 5) are shown in Fig. 6. It implies that there have been two episodes of rapid uplift along the West Kunlun Range: one in the mid-Miocene ( $\sim 16-11 \mathrm{Myr})$ and the other since $\sim 5 \mathrm{Myr}$, with the latter being significantly more rapid. The peak deposition/subsidence rate for the depocenter was $\sim 0.4 \mathrm{~mm}$ per year during mid-Miocene and $\sim 1.3 \mathrm{~mm}$ per year for the Quaternary (Fig. 6).

Using the differences in thickness between strata on the two sides of the frontal thrust (Figs 1 and $4 \mathrm{a}, \mathrm{b}$ ), we calculated the relative uplift rate on the hanging wall for each time interval by dividing the thickness difference $\left(S_{0}-S_{1}\right)$ for each unit by the estimated geological duration $\Delta t$. The results also indicate two episodes of rapid uplift along the frontal thrust of the West Kunlun Range: one during the Miocene ( $23-12 \mathrm{Myr})$ with a peak rate of $\sim 0.2 \mathrm{~mm}$ per year and the other during the Quaternary (after $2.6 \mathrm{Myr}$ ) with a much higher rate of $0.7 \mathrm{~mm}$ per year (Table 2 and Fig. 6). 


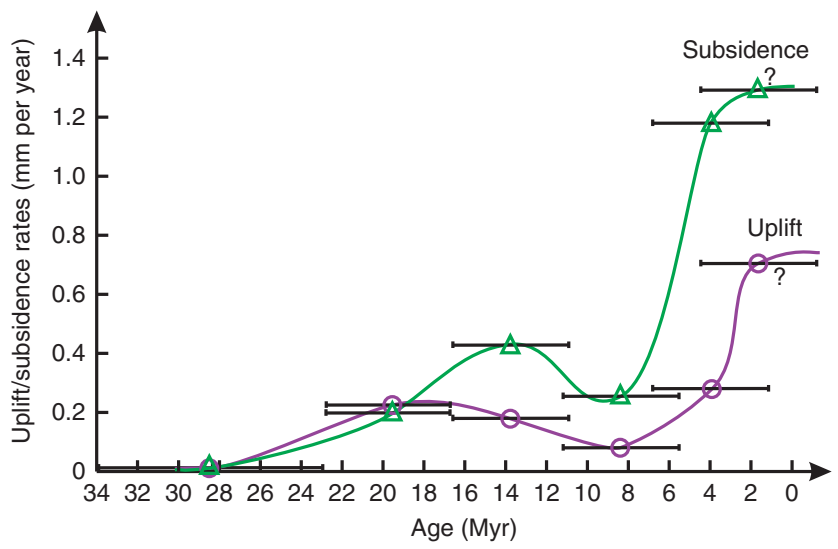

Figure 6 | Episodic uplift and foreland subsidence. Time variations in the average uplift rate (purple) of the hanging wall of the frontal thrust relative to the footwall, estimated using the thickness contrasts of strata units $E_{3 \text {, }}^{1}$ $N_{1}^{1}, N_{1}^{2}, N_{1}^{3}, N_{2}$ and $Q$ (Table 2), and estimated average subsidence rates (green, using data from Table 1 and Fig. 5b), at the depocenter of the foredeep (position 1 in Fig. 5a).

\section{Table 2 | Results of relative uplift rate at the foothills of the West Kunlun Range across the frontal thrust.}

\begin{tabular}{lrrlc} 
Stratum & $\mathbf{S}_{\mathbf{0}}(\mathbf{m})$ & $\mathbf{S}_{\mathbf{1}}(\mathbf{m})$ & $\boldsymbol{\Delta t} \mathbf{( M a})$ & Uplift rate $(\mathbf{m m}$ per year) \\
\hline $\mathrm{Q}$ & 3,885 & 2,060 & $2.6-0.01$ & 0.7046 \\
$\mathrm{~N}_{2}$ & 1,893 & 1,137 & $5.3-2.6$ & 0.2801 \\
$\mathrm{~N}_{1}^{3}$ & 1,339 & 831 & $11.6-5.3$ & 0.0805 \\
$\mathrm{~N}_{1}^{2}$ & 1,157 & 371 & $16-11.6$ & 0.1788 \\
$\mathrm{~N}_{1}^{1}$ & 1,943 & 366 & $23-16$ & 0.2252 \\
$\mathrm{E}_{3}^{1}$ & 199 & 197 & $34-23$ & 0.0002 \\
\hline
\end{tabular}

$\mathrm{S}_{0}$, maximum thickness of a formation in the foredeep; $\mathrm{S}_{1}$, thickness of a formation on the hanging wall of the frontal thrust; $\Delta \mathrm{t}$, time duration in Myr.

\section{Discussion}

The fact that the relative uplift rate across the frontal thrust shows a comparable periodicity and relative intensity as that suggested by the subsidence/deposition rate estimations (Fig. 6) indicates that (a) the frontal thrust acted broadly synchronously with the main orogenic belt and (b) the interpreted two-episode uplift history, with the post $5 \mathrm{Myr}$ one being much stronger $(\sim 3$ times that of the earlier one), is a realistic reflection of the uplift history along the West Kunlun Range. The intensity contrast between the two episodes likely indicates that, during the first episode, the front of the proto-West Kunlun orogen at the edge of the plateau was further south from its present position, and it only propagated to its present position during the second episode. Our results therefore suggest that the northwestern edge of the Tibetan Plateau underwent two major episodes of propagation since $\sim 23 \mathrm{Myr}$ : one at $\sim 23-12 \mathrm{Myr}$ and the other since $5 \mathrm{Myr}$, leading to the region being uplifted from near sea-level ${ }^{10}$ to the present height of $>6,000 \mathrm{~m}(\sim 5,000 \mathrm{~m}$ relative to the Tarim foreland basin). Such a two-episode uplift history is comparable to the two episodes of rapid cooling events recorded along the eastern margin of the Tibetan Plateau ${ }^{3}$.

We therefore conclude that the Tibetan Plateau likely experienced two major episodes of lateral propagation towards both its eastern and northern margins after $\sim 25$ Myr: one mostly before $10 \mathrm{Myr}$ and the other mostly after $5 \mathrm{Myr}$. Such a semisynchronous plateau expansion model is at variance with both the synchronous plateau-wide uplift ${ }^{1}$ and the dominantly northward plateau propagation models ${ }^{2}$. Recent work on both margins also suggest that brittle thickening of the upper crust plays the dominant role in the plateau propagation along those margins ${ }^{29,30}$. There is therefore a case for synchronous episodic plateau expansion dominantly through brittle thickening of the upper crust rather than mechanisms like crustal channel flow ${ }^{31,32}$.

\begin{abstract}
Methods
Subsidence rate calculation. Subsidence rates at 12 locations along the seismic traverse in the southwestern Tarim foreland basin (Fig. 5a) are calculated for the time intervals of the Oligocene $\left(\mathrm{E}_{3}^{1}\right)$, the Miocene $\left(\mathrm{N}_{1}^{1}, \mathrm{~N}_{1}^{2}\right.$, and $\left.\mathrm{N}_{1}^{3}\right)$ and the Pliocene $\left(\mathrm{N}_{2}\right)$ epochs, and the Quaternary (Q) period (Figs 2 and 4). Seismic reflection data show that the syntectonic foreland basin growth strata are above the Oligocene Bashiblake Formation ( $\mathrm{E}_{3}^{1}$ ) (Figs $4 \mathrm{c}$ and 5a), consisting of the Miocene Keziluoyi $\left(\mathrm{N}_{1}^{1}\right)$, Anjuan $\left(\mathrm{N}_{1}^{2}\right)$ and Pakbulak $\left(\mathrm{N}_{1}^{3}\right)$ formations, the Pliocene Artux Formation $\left(\mathrm{N}_{2}\right)$ and the Quaternary Xiyu Formation (Figs 2 and 5a). Between wells MC1 and $\mathrm{SH} 2$ (Fig. $4 \mathrm{c}$ ) there is an $\sim 60-\mathrm{km}$ separation when projected onto the transect. The thickness of the individual formations increases from north to south: the Bashiblake Formation from 108 to $120 \mathrm{~m}$, the Pakbulak Formation from 300 to $710 \mathrm{~m}$, the Anjuan Formation from 400 to $550 \mathrm{~m}$, the Keziluoyi Formation from 290 to $450 \mathrm{~m}$, the Artux Formation from 810 to 1,834 m and the Xiyu Formation from 1,393 to 1,964 (points 12 and 8 of Fig. 4c). These correspond to average sedimentation rates of $0.01,0.04,0.09,0.05,0.30$ and $0.54 \mathrm{~mm}$ per year for each corresponding time interval at well MC1 (location No. 12), and 0.01, 0.10, 0.13, $0.07,0.68$ and $0.76 \mathrm{~mm}$ per year at well SH2 (location No. 8), respectively. These numbers (highlighted in shade) were used for calibrating the rate estimation for the other 10 locations along the transect (Table 1 and plots in Fig. 5b).
\end{abstract}

Relative uplift rate calculation. The relative uplift rate between the two sides of the frontal thrust at the foothills of the West Kunlun Range is estimated for the time intervals of the Oligocene $\left(\mathrm{E}_{3}^{1}\right)$, the Miocene $\left(\mathrm{N}_{1}^{1}, \mathrm{~N}_{1}^{2}\right.$, and $\left.\mathrm{N}_{1}^{3}\right)$, the Pliocene $\left(\mathrm{N}_{2}\right)$ and the Quaternary $(\mathrm{Q})$ using the difference in strata thickness across the fault $\left(\mathrm{S}_{\mathrm{o}}\right.$ and $\mathrm{S}_{1}$ as in Fig. $\left.4 \mathrm{~b}\right)$ divided by the respective time duration.

\section{References}

1. Powell, C. M. Continental underplating model for the rise of the Tibetan Plateau. Earth Planet. Sci. Lett. 81, 79-94 (1986).

2. Tapponnier, P. et al. Oblique stepwise rise and growth of the Tibet plateau. Science 294, 1671-1677 (2001).

3. Wang, E. et al. Two-phase growth of high topography in eastern Tibet during the Cenozoic. Nat. Geosci. 5, 640-645 (2012).

4. Wang, E., Wan, J. L. \& Liu, J. Q. Late Cenozoic geological evolution of the foreland basin bordering the West Kunlun range in Pulu area: Constraints on timing of uplift of northern margin of the Tibetan Plateau. J. Geophys. Res. 108, 2401-2413 (2003).

5. Zheng, H. B., Powell, C., An, Z., Zhou, J. \& Dong, G. Pliocene uplift of the northern Tibetan Plateau. Geology 28, 715-718 (2000).

6. Yin, A. et al. Tectonic history of the Altyn Tagh fault system in northern Tibet inferred from Cenozoic sedimentation. Geol. Soc. An. Bull. 114, 1257-1295 (2002).

7. Haq, B. U., Hardenbol, J. \& Vail, P. R. Chronology of fluctuating sea levels since the Triassic. Science 235, 1156-1166 (1987).

8. Bosboom, R. E. et al. Late Eocene sea retreat from the Tarim Basin (west China) and concomitant Asian paleoenvironmental change. Palaeogeogr. Palaeoclimatol. Palaeoecol. 299, 385-398 (2011).

9. Sobel, E. R. \& Dumitru, T. A. Thrusting and exhumation around the margins of the western Tarim Basin during the India-Asia collision. J. Geophys. Res. 102, 5043-5063 (1997).

10. Ritts, B. D. et al. From sea level to high elevation in 15 million years: Uplift history of the northern Tibetan Plateau margin in the Altun Shan. Am. J. Sci. 308, 657-678 (2008)

11. Li, G. J., Pettke, T. \& Chen, J. Increasing Nd isotopic ratio of Asian dust indicates progressive uplift of the north Tibetan Plateau since the middle Miocene. Geology 39, 199-202 (2011).

12. Zheng, H. B., Huang, X. T. \& Butcher, K. Lithostratigraphy, etrography and facies analysis of the Late Cenozoic sediments in the foreland basin of the West Kunlun. Palaeogeogr. Palaeoclimatol. Palaeoecol. 241, 61-78 (2006).

13. Tada, R., Zheng, H. B. \& Sugiura, N. Desertification and dust emission history of the Tarim Basin and its relation to the uplift of northern Tibet. Geol. Soc. London Spec. Publ. 342, 45-65 (2010).

14. Wang, C. S. et al. Outward-growth of the Tibetan Plateau during the Cenozoic: A review. Tectonophysics 621, 1-43 (2014).

15. Avouac, J. P. \& Peltzer, G. Active tectonics in southern Xinjiang, China: Analysis of terrace riser and normal fault scarp degradation along the Hotan-Qira fault system. J. Geophys. Res. 98, 21773-21807 (1993).

16. Lyon-Caen, H. \& Molnar, P. Gravity anomalies and the structure of western Tibet and the southern Tarim basin. Geophys. Res. Lett. 11, 1251-1254 (1984).

17. Matte, P. et al. Tectonics of Western Tibet, between the Tarim and the Indus. Earth Planet. Sci. Lett. 142, 311-330 (1996). 
18. Wittlinger, G. et al. Teleseismic imaging of subducting lithosphere and Moho offsets beneath western Tibet. Earth Planet. Sci. Lett. 221, 117-130 (2004).

19. Jiang, X. D., Jin, Y. \& McNutt, M. Lithospheric deformation beneath the Altyn Tagh and West Kunlun faults from recent gravity surveys. J. Geophys. Res. 109, B05406 (2004).

20. Wang, Z. H. Tectonic evolution of the western Kunlun orogenic belt, western China. J. Asian Earth Sci. 24, 153-161 (2004).

21. Zhou, Z. Y., Chen, P. J. \& Wang, Y. J. Stratigraphy of the Tarim Basin 60-87 (Science Press, 2000).

22. Xinjiang BGM (Bureau of Geology and Mineral Resources of Xinjiang Uygur Autonomous Region). Regional Geology of Xinjiang Uygur Autonomous Region 121-150 (Geol. Publ. House, 1993).

23. GRISOC (Geological Research Institute of Shengli Oil Complex). The tectonic Evolution of Hetian Explored Area in Tarim 21-28 49-66 and 101-112 (Internal publication, Geological Research Institute of Shengli Oil Pty Ltd, 2000).

24. Sun, J. \& Liu, T. The age of the Taklimakan Desert. Science 312, 1621 (2006).

25. Hao, Y. C. et al. Neogene Stratigraphy and Palaeogeography in the Western Tarim Basin. Acta Geol. Sin. 76, 387-391 (2002).

26. Gradstein, F. M., Ogg, J. G., Schmitz, M. D. \& Ogg, G. The Geologic Time Scale 2012 63-83 (Elsevier Science Ltd, 2012).

27. Coutand, I. et al. Late Cenozoic tectonic development of the intramontane Alai Valley (Pamir-Tien Shan region, Central Asia). Tectonics 21, 1053-1072 (2002).

28. Lacassin, R. et al. Large-scale geometry, off set and kinematic evolution of the Karakorum fault, Tibet. Earth Planet. Sci. Lett. 219, 255-269 (2004).

29. Jiang, X. D., Li, Z. X. \& Li, H. B. Uplift of the West Kunlun Range, northern Tibetan Plateau, dominated by brittle thickening of the upper crust. Geology 41, 439-442 (2013).

30. Hubbard, J. \& Shaw, J. H. Uplift of the Longmen Shan and Tibetan plateau, and the 2008 Wenchuan $(M=7.9)$ earthquake. Nature 458, 194-197 (2009).
31. Royden, L. H. et al. Surface deformation and lower crustal flow in eastern Tibet. Science 276, 788-790 (1997)

32. Royden, L. H., Burchfiel, B. C. \& Robert, D. H. The Geological Evolution of the Tibetan Plateau. Science 321, 1054-1058 (2008).

\section{Acknowledgements}

We thank Dongsheng Liu for assistance with the verification of the fossil record, Siyou Tong for seismic reflection data processing and interpretation, Deyong $\mathrm{Li}$ and Shan $\mathrm{Hu}$ for figure drafting, and Simon Wilde and Steve Reddy for proofreading and commenting. This work was funded by NSFC (40772124 and 41176038) and CGS (GZH200900504). This is TIGeR paper 585, and contribution 496 from ARC Centre of Excellence in Core to Crust Fluid Systems.

\section{Author contributions}

X.-D.J. initiated the study. X.-D.J. and Z.-X.L. jointly designed the paper, carried out the rate calculations and interpretations, and wrote the paper.

\section{Additional information}

Competing financial interests: The authors declare no competing financial interests.

Reprints and permission information is available online at http://npg.nature.com/ reprintsandpermissions/

How to cite this article: Jiang, X.-D. and Li, Z.-X. Seismic reflection data support episodic and simultaneous growth of the Tibetan Plateau since $25 \mathrm{Myr}$. Nat. Commun. 5:5453 doi: 10.1038/ncomms6453 (2014). 